\title{
Hypoxia attenuate ionic transport in the isolated gill epithelium of Carcinus maenas
}

\section{Čedomil Lucu}

Journal of Comparative Physiology B

Biochemical, Systems, and

Environmental Physiology

ISSN 0174-1578

Volume 190

Number 4

J Comp Physiol B (2020) 190:391-401

DOI 10.1007/s00360-020-01277-2 
Your article is protected by copyright and all rights are held exclusively by SpringerVerlag GmbH Germany, part of Springer Nature. This e-offprint is for personal use only and shall not be self-archived in electronic repositories. If you wish to self-archive your article, please use the accepted manuscript version for posting on your own website. You may further deposit the accepted manuscript version in any repository, provided it is only made publicly available 12 months after official publication or later and provided acknowledgement is given to the original source of publication and a link is inserted to the published article on Springer's website. The link must be accompanied by the following text: "The final publication is available at link.springer.com". 


\title{
Hypoxia attenuate ionic transport in the isolated gill epithelium of Carcinus maenas
}

\author{
Čedomil Lucu, ${ }^{1,2}$
}

Received: 29 October 2019 / Revised: 31 March 2020 / Accepted: 8 April 2020 / Published online: 24 April 2020

c) Springer-Verlag GmbH Germany, part of Springer Nature 2020

\begin{abstract}
The gills are osmorespiratory organs of aquatic organisms and the prime target of environmentally induced hypoxia. We have studied the impact of severe hypoxia $\left(0.5 \mathrm{mg} \mathrm{O}_{2} / \mathrm{L}\right)$ on the ionic transport across posterior gills of Carcinus maenas acclimated to $12 \mathrm{ppt}$ seawater (DSW). The short-circuit current (Isc) across hemilamellae from gills i.e. active ion transport was studied in micro Ussing chambers. Hypoxia induced by deoxygenation of the basolateral side, and not the apical side, resulted in time-dependent inhibition of Isc and full recovery of Isc after reoxygenation. Exposure of the crabs to severe $7 \mathrm{~h}$ hypoxia decreased the specific activity of $\mathrm{Na}^{+}, \mathrm{K}^{+}$-ATPase in the gills by $36 \%$. Full recovery of enzyme activity occurred in fasted crabs after 3 days of reoxygenation. The intensity of Western blotting bands was not different in the gills of oxygenated, hypoxic and reoxygenated crabs. The reversible, nonspecific blocker of $\mathrm{K}^{+}$channels $\mathrm{Cs}$ and hypoxia inhibited over $90 \%$ of Isc which is after reoxygenation fully recovered. The specific blocker of $\mathrm{Cl}^{-}$channels NPPB [5-nitro-2-(3-phenylpropylamino) benzoic acid] blocked Isc by $68.5 \%$. Only the rest of not inhibited Isc in aerated saline was blocked by hypoxia and recovered after reoxygenation. The activity of the antioxidant enzyme catalase was not changed during hypoxia and reoxygenation kept the high enzyme activity in the gills at the level of crabs acclimated to DSW. As a response to hypoxia the presence of $2 \mathrm{mM} \mathrm{H}_{2} \mathrm{O}_{2}$ induce an initial slight transient decrease of Isc followed by a rise and after reoxygenation fully recovered Isc. Incubation of hemilamellae with the antioxidant derivative Trolox did not affect the inhibition of Isc by hypoxia.
\end{abstract}

Keywords Carcinus $\cdot$ Posterior gills $\cdot$ Ussing-chamber $\cdot$ Ion channels $\cdot \mathrm{Na}^{+}, \mathrm{K}^{+}$-ATPase $\cdot$ Catalase

\section{Introduction}

Hypoxia is a severe global phenomenon affecting physiological, morphological and behavioral changes of aquatic organisms with strong implications on the ecosystem (Burnett and Stickle 2001; Diaz and Rosenberg 2008; Riedel et al. 2012). Living in the intertidal zone, Carcinus maenas is tolerant to environmental fluctuations, and as invasive intertidal species in world seas widely used as an ecotoxicological model for effects of anthropogenic pollutants (Leignel et al. 2014).

Communicated by Bernd Pelster.

Čedomil Lucu

lucu@irb.hr

1 Center for Marine Research, Institute Ruđer Bošković, Rovinj, Zagreb, Croatia

2 Alfred Wegener-Institute Helmholtz Centre for Polar and Marine Research, Wadden Sea Station List, Sylt, Germany
Hypoxia induces ion regulation and acid-base disturbances in Carcinus maenas (Johnson and Uglow 1987), and crabs use metabolic depression as a strategy to survive hypoxia (Durand and Regnauld 1998). Decrease in hemolymph $\mathrm{Na}^{+}$and $\mathrm{Cl}^{-}$concentrations in Carcinus maenas is evident in hypoxia/heavy metal combination in low salinity exposures (Johnson 1988). Impaired ionic regulation in hypoxia-anoxia has been observed in osmoregulating shrimps Crangon crangon and Palaemon adspersus. For these species, anaerobic metabolism means a slow breakdown of the main transporting functions and of the tissue osmolarity resulting in cell damage ( Hagerman and Uglow 1981). The osmoregulatory capacity of the peneid shrimp Penaeus vannamei was depressed by exposure to low oxygen tension and fully recovered after reoxygenation (Charmantier et al. 1994). Combination of temperature and hypoxia during molt stage had a significant effect on the osmoregulatory capacity of the shrimp Litopenaeus stylirostris. Low temperature reduced the effect of hypoxia presumably by slowing down the metabolism (Chantal and Claude 2005). In 
the freshwater prawn Macrobrachium rosenbergii exposed to hypoxia significant decrease in hemolymph osmolality, $\mathrm{Na}^{+}, \mathrm{K}^{+}$and $\mathrm{Cl}^{-}$concentrations were observed (Cheng et al. 2003). The effect on $\mathrm{Na}^{+}$level in hemolymph had its onset in Hemigrapsus sexdentatus which is less tolerant to hypoxia than H. crenilatus (Falconer et al. 2019).

The posterior gills of euryhaline hyperosmoregulating shore crab Carcinus maenas are recognized as highly efficient ion- osmoregulatory system evolved to adapt to changes in external osmolarity (Henry et al. 2012). The gills are the prime organ in crabs and fish to come into contact with gas and ion changes in water and, therefore, the first target in the oxygen depletion and ion fluctuations in water (Claiborne et al. 2002; Henry et al. 2012). Short-circuit current across the one epithelium layer of the posterior Carcinus gills was substantially reduced under exposure to $1.6-2.5 \mathrm{mg}$ $\mathrm{O}_{2}$ hypoxic saline (Lucu and Ziegler 2017). Moreover, in the shore crab increased surface/volume ratio in mitochondrion during hypoxia might be an adaptive mechanism that maximizes the efficiency of $\mathrm{O}_{2}$ respiration enabling oxidative phosphorylation under restricted oxygen content (Lucu and Ziegler 2017). In the killifish were studied electrogenic and diffusive components of transepithelial potential (TEP) across the gill tissue under hypoxia. TEP was reduced by hypoxia would be deleterious to ionoregulatory balance in SW acclimated killifish (Wood and Grosell 2015).

The epithelial cells of posterior crab gills contain numerous mitochondria at the basolateral membrane (Barra et al. 1983; Compere et al. 1989). The mitochondrial respiratory chain requires $\mathrm{O}_{2}$ and regenerates ATP from ADP and phosphate. This ATP drives numerous cellular processes in crustacean gills, including $\mathrm{Na}^{+}, \mathrm{K}^{+}$-ATPase, responsible for active salt absorption in hyperosmoregulating Carcinus (see Henry et al. 2012). However, the effects of hypoxia on the gill $\mathrm{Na}^{+}, \mathrm{K}^{+}$-ATPase in crabs was poorly studied. In European flounder, the activity of $\mathrm{Na}^{+}, \mathrm{K}^{+}$-ATPase in gills is reduced by hypoxia without influence on the extracellular ion concentrations (Lundgreen et al. 2008). Branchial $\mathrm{Na}^{+}, \mathrm{K}^{+}$-ATPase hydrolytic activity in the gills of fish Astronotus ocellatus was depressed by hypoxia (Wood et al. 2007; Richards et al. 2007). Hypoxia induces a decrease of the $\mathrm{Na}^{+}, \mathrm{K}^{+}$-ATPase activity by promoting the endocytosis of catalytic alpha subunit from the plasma membrane into intracellular pool (Bertorello et al. 1999; Dada et al. 2003). Enhanced resistance to hypoxia might develop if the adapted cells could selectively preserve a limited energy production for indispensable functions necessary for living cells. During metabolic depression, protein synthesis and degradation, and ion-dependent ATPase activity are drastically suppressed (Hochachka et.al. 1996; Boutilier and St Pierre 2000; Hochachka and Somero 2002; Larade and Storey 2002; Gorr et al. 2006). Hypoxia diminishes ATP utilization by downregulating protein translation and the $\mathrm{Na}^{+}, \mathrm{K}^{+}$-ATPase activity (Storey and Storey 1990; Guppy et al. 1994; Lee and Langhans 2015). Studies in vertebrates epithelia have reported that hypoxia reversibly blocks $\mathrm{Na}^{+}, \mathrm{K}^{+}$-ATPase activity (Planes et al. 1996; Mairbaurl et al. 2002; Wodopia et al. 2000; Dada et al. 2003).

Hypoxia inhibits background $\mathrm{K}^{+}$channels that are open at the resting potential of neuroepithelial cells of the zebrafish gills (Jonz et al. 2004), without the similar effect in hypoxia/ anoxia tolerant goldfish (Zacher et al. 2017). Depolarization by hypoxia in some mammal tissues occurs due to inhibition or limitation of $\mathrm{K}^{+}$channels activities. Identity of the specific $\mathrm{K}^{+}$channel subtypes responsible for chemoreceptor $\mathrm{O}_{2}$ sensing remains in debate and may vary with species (Lopez-Barneo et al. 1997; Shimoda and Polak 2011). In epithelial cells, $\mathrm{K}^{+}$channels are required for the recycling of $\mathrm{K}^{+}$taken up by the $\mathrm{Na}^{+}-\mathrm{K}^{+}$pump in exchange for $\mathrm{Na}^{+}$. Therefore, these channels contribute to the negative membrane potential required for the uptake of $\mathrm{Na}^{+}$and control transepithelial transport. It is unclear whether these $\mathrm{K}^{+}$channels respond to changes in oxygen tension similar to what is found in excitatory cells (Dawson et al. 1980).

Gills exhibit response to oxidative stress and provide a first line of antioxidant defense in crabs and fish. Strategy in the gills of king crab Lithoder santella during air exposure is to counteract the overproduction of reactive oxygen species (ROS) to develop a permanently high level of SOD activity favoring the degradation of superoxide radicals which generates $\mathrm{H}_{2} \mathrm{O}_{2}$ (Schwezov et al. 2017). In the gills of the crab Chasmagnathus granulata (Dane 1851; Neohelice granulata) daily variations of the antioxidant system should depend on high catalase activity (Maciel et al. 2004). Higher catalase activity was acquired in the crab Scyilla paramamosian after induced oxidative stress by lipopolysaccharide (LPS) (Liu et al. 2010). Oxygen sensitive potassium flux in the erythrocytes of rainbow trout is regulated by reactive oxygen species (Berenbrink et al. 2005; Bogdanova and Nikinmaa 2001).

The mechanisms by which oxygen influence ionic membrane transport i.e. short-circuit current in crabs gills are poorly studied. The objective of this study is to determine how stress induced by hypoxia is associated with electrogenic ion transport in the posterior gills of Carcinus maenas. Do changes in Isc observed during hypoxia/reoxygenation represent changes in specific transport mechanisms i.e. $\mathrm{K}^{+}$ and $\mathrm{Cl}^{-}$channels? Does $\mathrm{Na}^{+}, \mathrm{K}^{+}$-ATPase specific activity change in posterior gills during short-term hypoxia of the crabs? Does antioxidant enzyme catalase change in posterior gills and reactive oxygen species (ROS) scavenger Trolox-C affect Isc inhibition by hypoxia and reoxygenation? 


\section{Material and methods}

\section{Animal acquisition and holding}

Adult shore crabs Carcinus maenas were collected from the Wadden Sea coast of Westerland (Sylt) in the period from September to November 2018. In the experiments, only intemoult adult male crabs were used. Animals were fed by bovine heart meat twice a week. Crabs were kept in aquaria with the open circuit of seawater (Institute Alfred Wegener, Sylt). Crabs were acclimated for at least two weeks in 12 ppt seawater prepared by diluting natural seawater by deionized water. The animals were kept in aerated aquaria at $18 \pm 2{ }^{\circ} \mathrm{C}$ and under natural light condition. The specific activity of the $\mathrm{Na}^{+}, \mathrm{K}^{+}$-ATPase in the posterior gills was measured in the DSW acclimated crabs exposed to severe hypoxia $\left(0.5 \mathrm{mg} \mathrm{O}_{2} / \mathrm{L}\right)$ for $7 \mathrm{~h}$. During the first hour of hypoxia, crabs were actively trying to escape from the tank. In the second hour of exposure, the crabs were largely inactive, with only oscillatory movement of the antenna and the third maxilliped. After $7 \mathrm{~h}$ the hypoxia tone of the claws had decreased, and a few minutes after reoxygenation, the tone was recovered. Survival of crabs under hypoxia necessities a considerable reduction in metabolic rate (Hill et al. 1991).

\section{Electrophysiological studies}

After destroying the ventral ganglion, the carapace was lifted and the four posterior pairs of gills were cut at the base by scissors and removed. We choose 7 th or 8 th posterior gills for our studies on the basis of findings on Carcinus and other Crustacea have measured the significantly higher specific activity of $\mathrm{Na}^{+}, \mathrm{K}^{+}$-ATPase over anterior ones, leading to the suggestion that the posterior gills are specialized for osmoregulation (Neufeld et al. 1980; Siebers et al. 1985).

Short circuit-current (Isc) was measured in the gill epithelium as described by Onken and Siebers 1992; Lucu and Flik 1999. Hemilamella consisting of a single epithelial layer supported by an apical layer of cuticle were prepared by splitting the gill lamella in half longitudinally. Native hemilamella epithelium isolated from crabs acclimated in normoxic DSW were used for measuring effects of hypoxia on Isc. This preparation was mounted in a modified Ussing micro-chamber with a circular aperture of $1.25 \mathrm{~mm}$ in diameter. The so-called dark area of the hemilamella, which is particularly rich in mitochondria rich cells was selected for the Isc measurements. The epithelium was positioned onto the aperture, which rim area was slightly greased to minimize edge damage. The criterion for the validity of the preparation was a stable Isc (for $>3 \mathrm{~h}$ ) when control physiological saline was applied. The electrical parameters of this preparation were measured using an automatic voltage clamp 558C-5 amplifier (Bioengineering, The University of Iowa, USA). The transepithelial potential was controlled by mercury reference electrodes (Broadley James Corporation; USA). Voltage pulses of $1.0 \mathrm{mV}$ (duration $1 \mathrm{~s} ; 500 \mathrm{~s}$. interval between pulses) were applied by a pulse generator to measure epithelial conductance.

The outputs from the voltage clamp were visualized using a pen recorder (Linseis Ly 17,100). The measured current across the hemilamella was corrected for each preparation following Ohm's law. In the hypoxia experiments at both sides of epithelium were perfused with identical crab saline, which was circulated by a two-channel Watson-Marlow peristaltic pump (Sci 400) at a flow rate of $0.5 \mathrm{~mL} / \mathrm{min}$. Perfusion saline was bubbled with compressed air and $\mathrm{N}_{2}$ gas to reach the desired $\mathrm{O}_{2}$ concentration at both sides of epithelia. The $\mathrm{O}_{2}$ concentration was measured by an oximeter, which electrode was immersed in the perfusion saline during an experiment (Oxytester,WTW ProfiLine oxy 1970, Germany). Oxygen content in normoxic saline ranged from 8.5 to $9.5 \mathrm{mg} \mathrm{O}_{2} / \mathrm{L}$ and $\mathrm{pH}$ values in the normoxic and groups exposed to hypoxia were $7.7 \pm 0.2$. The crab saline contained (in $\mathrm{mM}$ ) to: $\mathrm{NaCl}, 235 ; \mathrm{KCl}, 5 ; \mathrm{MgCl}_{2}, 4.0 ; \mathrm{CaCl}_{2}$ 2.2; $\mathrm{NaHCO}_{3}, 6$; glucose, 10; HEPES, 10. pH of 7.6 was adjusted by TRIS base (see Lucu and Flik 1999).

\section{$\mathrm{Na}^{+}, \mathrm{K}^{+}$-ATPase determination}

After dissection, posterior gill pairs were slightly dried on filter paper. Posterior pooled gills were homogenized in a ice-cold hypotonic buffer $(10 \mathrm{~mL} / \mathrm{g}$ fresh weight $)$ in Dounced homogenizer by 50 strokes. The homogenate was filtered through $0.1 \mathrm{~mm}$ nylon mesh and centrifuged at $450 \times g$ for $20 \mathrm{~min}$ to remove the nuclear fraction and cellular debris. Homogenization medium contained (in $\mathrm{mmol} / \mathrm{L}$ ): $12.5 \mathrm{NaCl}, 1$ HEPES, 1 DTT (dithiotreitol), 0.5 EDTA, pH $8-8.1$ by TRISMA base, and the protease inhibitor aprotinin (0.1 mL/100 mL;Sigma).

$\mathrm{Na}^{+}, \mathrm{K}^{+}$-ATPase activity was determined by a slightly modified methodology described in detail earlier (Lucu and Flik 1999). $\mathrm{Na}^{+}, \mathrm{K}^{+}$-ATPase activity was assayed in triplicate by incubating $50 \mu \mathrm{L}$ of homogenate with $500 \mu \mathrm{L}$ assay solution A or E. A contains (in mmol/L): $100 \mathrm{NaCl}, 5.0 \mathrm{MgCl}_{2}$, 0.1 EDTA, 15 imidazol/histidine ( $\mathrm{pH}$ 7.5), $3 \mathrm{Na}_{2}$ ATP and $12.5 \mathrm{KCl}$. $\mathrm{E}$ is composed as A but $\mathrm{KCl}$ is omitted and ouabain $(1 \mathrm{mmol} / \mathrm{L})$ is added. The difference in phosphate released from ATP in solutions A and $\mathrm{E}$ reflects the ouabain -sensitive $\mathrm{K}$ dependent $\mathrm{Na}^{+}, \mathrm{K}^{+}$-ATPase. After incubation in thermostatted bath at $37^{\circ} \mathrm{C}$, for $15 \mathrm{~min}$, the reaction was stopped by addition of $1 \mathrm{ml}$ ice-cold $8.6 \%$ trichloroacetic 
acid. Liberated phosphate was quantified colorimetrically by addition of $1 \mathrm{ml}$ of $1.14 \%$ (wt/vol) ammonium heptamolybdate in sulfuric acid ( $36.3 \mathrm{ml}$ concentrated sulfuric acid/L distilled water), supplemented immediately before use with $4.5 \mathrm{~g} / 50 \mathrm{ml} \mathrm{FeSO}{ }_{4} \times 7 \mathrm{H}_{2} \mathrm{O}(9.0 \mathrm{~g} / 100 \mathrm{~mL})$ After about 20 min incubation the change in absorbance at $700 \mathrm{~nm}$ was recorded. Sigma Phosphate standard $0.65 \mathrm{mmol} / \mathrm{L}$ (Sigma) was used for expression of enzyme activity in Pi units.

\section{Western blotting}

Posterior gills were homogenized using a Dounce homogenization device (30 strokes). The homogenate was filtered over cheese cloth $(100 \mu \mathrm{m}$ mesh $)$. Filtrate was spin for $5 \mathrm{~min}$ at $400 \mathrm{~g}$ to remove nuclei and cellular debris. The membranes were collected by centrifugation for $40 \mathrm{~min}$ at $50.000 \mathrm{~g}$. The pelletetized membranes were resuspended in a small volume of buffer containing (in mmol/L) 300 sucrose, 10 HEPES/ Tris (pH 7.4), 2 DTT, 0.5 EDTA and $10 \mathrm{U} / \mathrm{ml}$ aprotinin. Protein was measured, and the suspension was brought to $2 \mathrm{mg} / \mathrm{mL}$ with the same buffer. Just before electrophoresis, $5 \mu \mathrm{L}$ membrane suspension was mixed with $10 \mu \mathrm{L}$ sample buffer (2 mM DTT, 0.5\% bromophenol blue, 30\% glycerol, $20 \mathrm{mM}$ Tris $\mathrm{HCl}, \mathrm{pH}, 6.8)$ microwave treated $(2 \times 1 \mathrm{~min}$ at $500 \mathrm{~W}$ ), this treatment was critical to extract a single immunoreactive species from the membrane preparation. Samples were run on $10 \%$ polyacrylamide slab gel; kaleidoscope prestained markers (Biorad No. 1610324 ) were used as a reference. After SDS-PAGE, proteins were electroblotted to nitrocellulose membranes (pore size $0.45 \mu \mathrm{m}$; Schleicher and Schuell, code 401196). After blocking the membranes with $3 \%$ low-fat coffee creamer plus $1 \%$ BSA and $0.1 \%$ gelatin, the proteins were probed with a mouse monoclonal antibody against the -subunit of an avian $\mathrm{Na}^{+}, \mathrm{K}^{+}$-ATPase (Developmental Study Hybridoma Bank, The University Iowa) for $1 \mathrm{~h}$ at room temperature and subsequently for $16 \mathrm{~h}$ at $4{ }^{\circ} \mathrm{C}$. Goat anti-mouse IgG-peroxidase conjugate was used to visualize the $\mathrm{Na}^{+}, \mathrm{K}^{+}$-ATPase epitope. Preparation was made of posterior gills obtained from crabs acclimated in DSW i.e. aerated, exposed to hypoxia $\left(0.5 \mathrm{mg} \mathrm{O}_{2} / \mathrm{L}\right)$ during $7 \mathrm{~h}$ and those reoxygenated 3 days after exposure to hypoxia.

\section{Catalase}

Catalase activity was studied by measuring the rate of degradation of $\mathrm{H}_{2} \mathrm{O}_{2}$ according to the method described by Claiborne (1985). Posterior gills 7 and 8 pairs were homogenized $(1: 25 \mathrm{w} / \mathrm{v})$ in the buffer containing $20 \mathrm{mM}$ HEPES, $1 \mathrm{mM}$ EDTA and $0.1 \%$ Triton $\mathrm{X}$ adjusted to $\mathrm{pH}$ 7.2. Homogenate was centrifuged at $10.000 \mathrm{~g}$ for $20 \mathrm{~min}$ at $4{ }^{\circ} \mathrm{C}$. The decrease in absorbance of $\mathrm{H}_{2} \mathrm{O}_{2}$ at a wavelength of $240 \mathrm{~nm}$ was recorded for a time period of $30 \mathrm{~s}$, taking measurements at $5 \mathrm{~s}$ intervals at $20{ }^{\circ} \mathrm{C}$. The values are expressed as $\mathrm{U} / \mathrm{mg}$ protein where $\mathrm{U}$ is $\mu \mathrm{mol} / \mathrm{min}$.

\section{Protein determination}

Protein content of homogenate and membrane vesicles was measured by Coomassie Brilliant Blue G-250 shifts from 465 to $595 \mathrm{~nm}$ when binding to protein occurs. Bradford procedure (BioRad catalog no 500-0002) using BSA as a reference. Protein BSA standards $1.29 \mathrm{mg} \mathrm{BSA} / \mathrm{mL}$.

\section{Statistics}

Data have been expressed as mean values \pm SEM. Statistical analyses were performed with SigmaPlot 10.0 (Systat Software Inc., San Jose, CA, USA). A one-way ANOVA was applied with a Tukey's post-hoc test. Significance for all statistical tests was accepted at $p<0.05$. Quantitation of Western blots was carried out determining the "adjusted volume" of immunoreactive protein bands (i.e. optical density multiplied with the area, $\mathrm{OD} \times \mathrm{mm}^{2}$ ) using molecular Analysis Software (Biorad, Hercules, CA).

\section{Chemicals}

Dimethylsulfoxide (DMSO), and 5-nitro-2-(3-phenylpropylamino)benzoic acid (NPPB soluble in DMSO) were obtained from Sigma-Aldrich. $\mathrm{CsCl}$ dissolved in a crab saline was used as a unselective inhibitor of $\mathrm{K}^{+}$channels (Van Driesche and Zeiske 1985). Trolox C (6-hydroxy2,5,7,8-tetramethylchroman-2 carboxylic acid soluble in water and $\mathrm{H}_{2} \mathrm{O}_{2}$ were obtained from Sigma-Aldrich.

\section{Results}

Once the hemilamella was mounted in the Ussing-type microchamber, the short-circuit current (Isc) reached baseline value in approximately $30 \mathrm{~min}$. Deoxygenation at the apical side of Carcinus hemilamella $\left(0.5 \mathrm{mg} \mathrm{O}_{2} / \mathrm{L}\right)$ and oxygenation of the basolateral side maintained Isc in the same range as the aerated control $\left(-279.4 \pm 19.2 \mathrm{~cm}^{-2}\right.$; Fig. 1). Within 20 min hypoxia at the basolateral side suppressed Isc $90 \%$, to $-28.2 \pm 4.0 \mathrm{~A} \mathrm{~cm}^{-2}$. High viability of the epithelium preparation was evidenced based on the recovery of Isc to $-254.6 \pm \mathrm{A} \mathrm{cm}^{-2}$ (Fig. 1). The Isc reflect the quantity of active ionic charge transfer (i.e. electrogenic transport) generated by $\mathrm{Na}^{+}, \mathrm{K}^{+}$-ATPase activity. The specific activity of the $\mathrm{Na}^{+}, \mathrm{K}^{+}$-ATPase in the posterior gills was measured in the crabs exposed to hypoxia $\left(0.5 \mathrm{mg} \mathrm{O}_{2} / \mathrm{L}\right)$ for $7 \mathrm{~h}$. Under these conditions, the activity of the enzyme was decreased $36 \%$, from $7.61 \pm 0.49$ (air; $n=8$ ) to $4.86 \pm 0.60 \mu \mathrm{M} \mathrm{Pi} / \mathrm{mg}$ protein/h (hypoxia; 


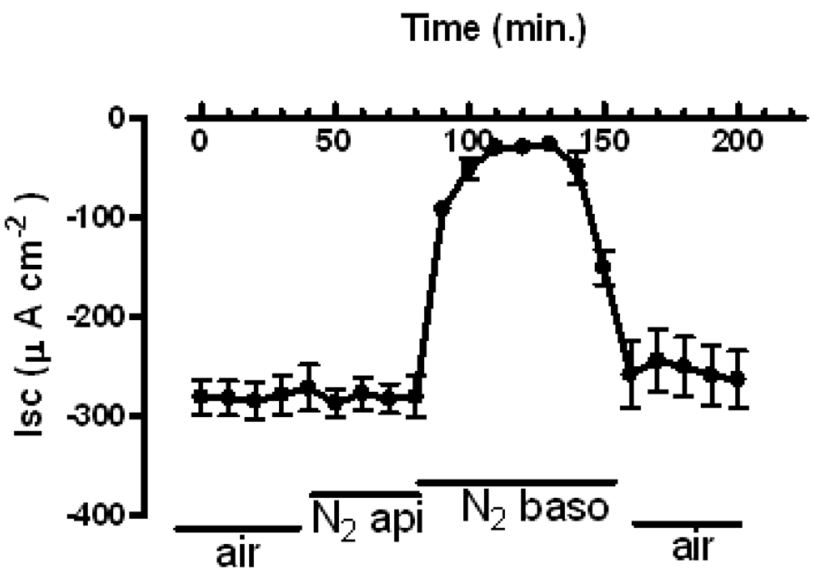

Fig.1 Time-course of the short-circuit current (Isc) across the hemilamella of the posterior gill exposed apically and basolaterally to deoxygenation $\left(0.5 \mathrm{mg} \mathrm{O}_{2} \mathrm{~L}^{-1}\right)$. Both sides of the epithelia were perfused initially with aerated saline. During $40 \mathrm{~min}$. deoxygenation of the apical side (basolateral side was aerated) Isc was not changed. When the basolateral side was deoxygenated (apical side was aerated) Isc was almost fully reduced. Isc was recovered during 30 min reoxygenation at both sides of epithelia. Mean values \pm S.E.M. per time point are given for four individual samples

$p<0.01 ; n=6$ ). Gradual increase of oxygen during $20 \mathrm{~h}$ reoxygenation increased the $\mathrm{Na}^{+}, \mathrm{K}^{+}$-ATPase activity to $6.33 \pm 0.37 \mathrm{M} \mathrm{Pi} / \mathrm{mg}$ protein $/ \mathrm{h}(p<0.05 ; n=6)$ and after 3 days of reoxygenation of fasted crabs, the specific activity of the enzyme had fully recovered $(7.39 \pm 0.51 \mathrm{M} \mathrm{Pi} /$ $\mathrm{mg}$ protein/h; $p>0.05 ; n=6$; Fig. 2). Western blot analysis

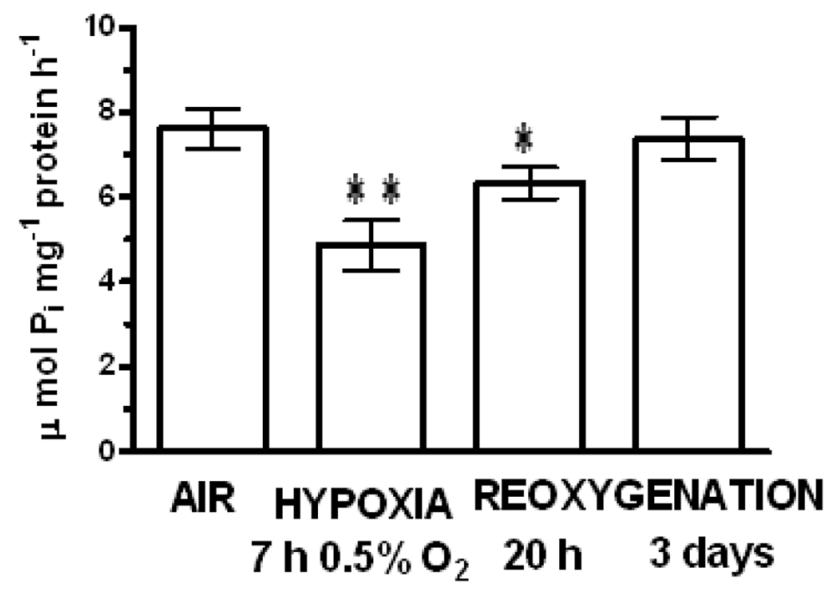

Fig. $2 \mathrm{Na}^{+}, \mathrm{K}^{+}$-ATPase activity in crude homogenates of the posterior gills in the control group compared with that exposed to hypoxia $(7 \mathrm{~h})$ and reoxygenated for $20 \mathrm{~h}$ and 3 days. Data are expressed as means of 5-8 individual samples \pm SEM. Statistical significance was calculated using one-way ANOVA and the Tukey's multiple comparision test. No significant differences were found between control (air) and group after 3 days reoxygenation. Significant difference was found between control and $7 \mathrm{~h}$ hypoxia $(p<0.01)$, and between control and $20 \mathrm{~h}$ reoxygenation $(p<0.05)$. ${ }^{*} p<0.05 ; * * p<0.01$

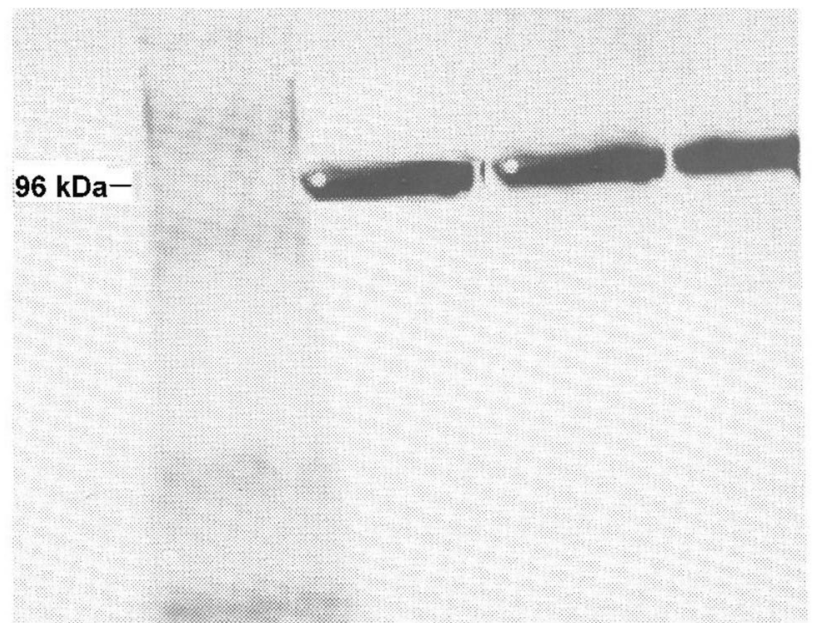

Fig.3 Western blot of $\mathrm{Na}^{+}, \mathrm{K}^{+}$-ATPase extracted from a homogenate of the posterior gills in the control aerated saline (line 1) and after $7 \mathrm{~h}$ (line 2) and 3 days deoxygenation (line 3) reoxygenation. Blots were probed with mouse monoclonal antibody against chicken $\mathrm{Na}^{+}, \mathrm{K}^{+}$-ATPase (cytosolic epitope of -subunit $\mathrm{kDa}$ recognizing a $100.4 \mathrm{kDa}$ protein at the prominent molecular species

of the posterior gill membrane preparation revealed that the $\mathrm{Na}^{+}, \mathrm{K}^{+}$-ATPase protein-subunit expression in membranes of deoxygenated and reoxygenated crabs did not differ from the control normoxic group (Fig. 3).

The effects of non-specific inhibitors of $\mathrm{K}^{+}$channels $(10 \mathrm{mM} \mathrm{CsCl})$ and $\mathrm{Cl}^{-}$channels $\left(1 \times 10^{-4} \mathrm{M} \mathrm{NPPB}\right)$ on the ion transport-related Isc at the basolateral side of the hemilamella was studied to gain insight into the possible participation of ion channels in hypoxia.

Hypoxic saline and $\mathrm{CsCl}$ containing aerated and hypoxic saline, respectively, inhibited more than $90 \%$ of Isc in comparison to the control aerated saline $(p<0.001)$. The non-inhibited portion of Isc remained at -8 to $-13 \mu \mathrm{A} \mathrm{cm}{ }^{-2}$ (Fig. 4). No significant difference between the non-inhibited portion of Isc in hypoxic versus $\mathrm{CsCl}$ saline, in the absence and presence of hypoxia, was found $(p>0.05)$. At the end of the experiments, Isc was fully recovered by reoxygenation (Fig. 4). The results suggest that hypoxia as well as $\mathrm{CsCl}$-sensitive non-specific $\mathrm{K}^{+}$ channels almost completely inhibits Isc.

In the NPPB-containing aerated saline, non-inhibited portions of Isc remained at $31.5 \%$, and in hypoxic saline, in the absence and presence of NPPB, Isc remained at $10.5 \%$ and $5.5 \%$, respectively, compared with the control group ( $p<0.001 ;$ Fig. 5.). There was no significant difference in Isc between the hypoxic groups in the presence and absence of NPPB $(p>0.05)$. During reoxygenation, only a portion of the Isc inhibited by hypoxia was recovered. The remainder was the non-recoverable portion of NPPBsensitive $\mathrm{Cl}^{-}$channels. 


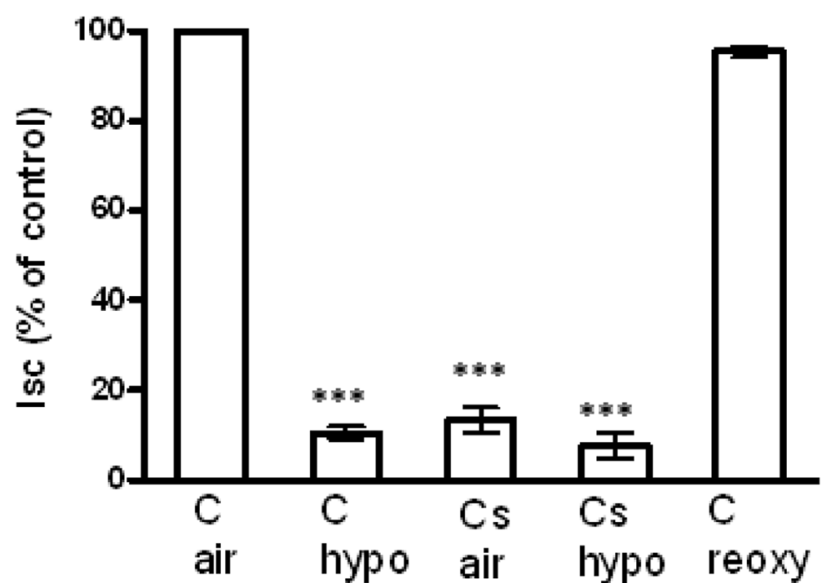

Fig. 4 Combined effects of hypoxia and the nonspecific inhibitor of $\mathrm{K}^{+}$channels $\mathrm{Cs}(10 \mathrm{mM} \mathrm{CsCl})$ on Isc in the hemilamella (basolateral side).We have measured consecutively Isc over $2.5 \mathrm{~h}$ period, and presented at the reached equilibrium relative to each group (means \pm SEM; $n=4)$. C air vs C hypo $(p<0.001)$; C air vs Cs air $(p<0.001)$ and vs Cs hypo $(p<0.001)$; C hypo vs Cs air $(p>0.05)$ and vs Cs hypo $(p>0.05)$. By reoxygenation Isc was recovered to the baseline value $(p>0.05) ; * * * p<0.001$

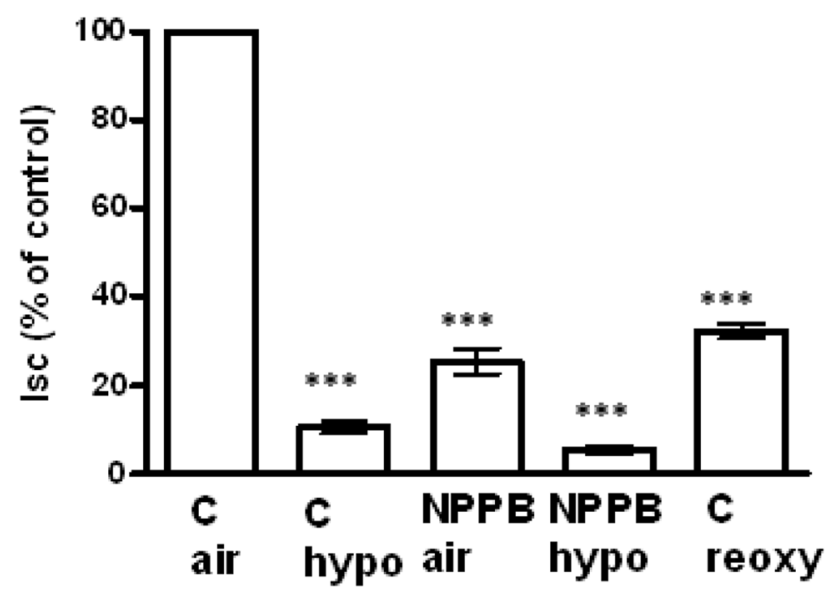

Fig. 5 Combined effects of hypoxia and the nonspecific blocker of $\mathrm{Cl}^{-}$channels NPPB $\left(1 \times 10^{-4} \mathrm{M}\right)$ on Isc in the hemilamella (basolateral side) of the crabs posterior gills. We have measured consecutively Isc over $2.5 \mathrm{~h}$ period and presented at the reached equilibrium relative to each group (means $\pm \mathrm{SEM} ; n=4)$. $\mathrm{C}$ air vs $\mathrm{C}$ hypo $(p<0.001)$; C air vs NPPB air $(p<0.001)$ and vs NPPB hypo $(p<0.001)$. C hypo vs NPPB hypo $(p>0.05)$. NPPB air vs $\mathrm{C}$ reoxy $(p>0.05) \mathrm{C}$ air vs $\mathrm{C}$ reoxy $(p<0.001)$. After reoxygenation portion of Isc inhibited by NPPB was not recovered; $* * * p<0.001$

The antioxidant catalase activity in posterior gills exposed to severe hypoxia $(113.6 \pm 24.1 \mathrm{U} / \mathrm{mg}$ protein; $n=5)$ for $7 \mathrm{~h}$ was not significantly different from the enzyme activity in the aerated control group $(126.0 \pm 15.0 \mathrm{U} / \mathrm{mg}$ protein; $p>0.05 ; n=5)$ and that after reoxygenation for $20 \mathrm{~h}$ $(131.0 \pm 28.1 \mathrm{U} / \mathrm{mg}$ protein; $p>0.05 ; n=5$; Fig. 6$)$.

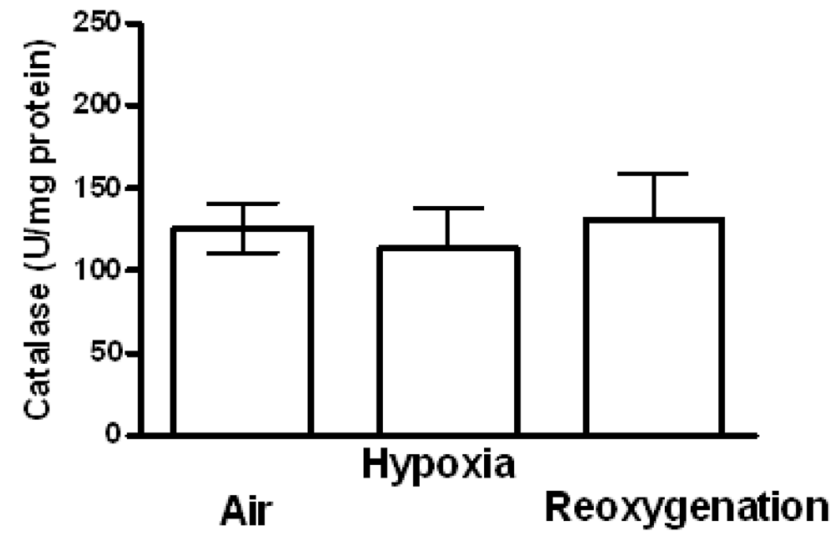

Fig.6 Catalase activity (U/mg protein) was measured in the posterior gills of crabs exposed to hypoxia for $7 \mathrm{~h}$ and afterwards maintained in normoxia for $20 \mathrm{~h}$. Data are expressed as means \pm SEM of 5-6 samples per treatment. Statistical significance was calculated using oneway ANOVA and the Tukey's multiple comparision test. No significant differences were found between control and treated groups

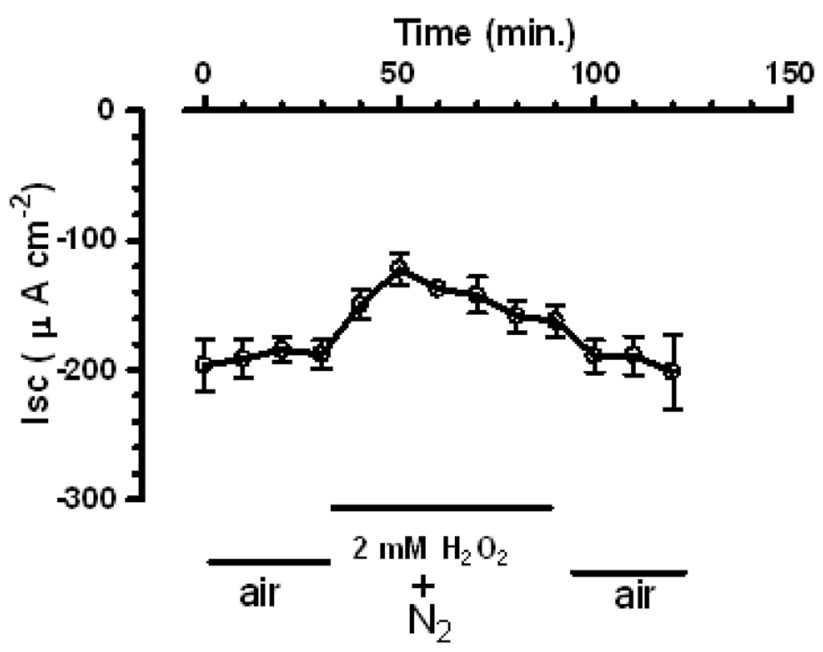

Fig.7 After reached steady-state, time-course of Isc in the hemilamella basolaterally incubated with deoxygenated saline containing $2 \mathrm{mM}$ hydrogen peroxide was studied. Isc transiently dropped by $33 \%$ and afterwards in the next 40 min steadily increase. During reoxygenation Isc was fully recovered to the value of the control saline. Mean values \pm S.E.M. per time point are given for four individual samples

Incubation of the basolateral side of the epithelium with $2 \mathrm{mM} \mathrm{H}_{2} \mathrm{O}_{2}$ in deoxygenated saline induced transient blockage of Isc, changing it from $-190.0 \pm 16.2 \mu \mathrm{A} \mathrm{cm}^{-2}$ to $-126.0 \pm 11.5 \mu \mathrm{A} \mathrm{cm}^{-2}$ at $30 \mathrm{~min}$ of exposure, but stimulated it during a further $40 \mathrm{~min}$ to $-160.4 \pm 12.3 \mu \mathrm{A} \mathrm{cm} \mathrm{cm}^{-2}$. At $30 \mathrm{~min}$ after reoxygenation, the Isc was recovered $\left(-193.2 \pm 18.6 \mu \mathrm{A} \mathrm{cm}^{-2}\right.$; Fig. 7)

Figure 8 (lower figure) shows the effect of hemilamella incubation with the antioxidant Trolox C $(200 \mu \mathrm{M})$ on Isc during deoxygenation and reoxygenation, and in comparison with the not incubated group (upper figure). During 

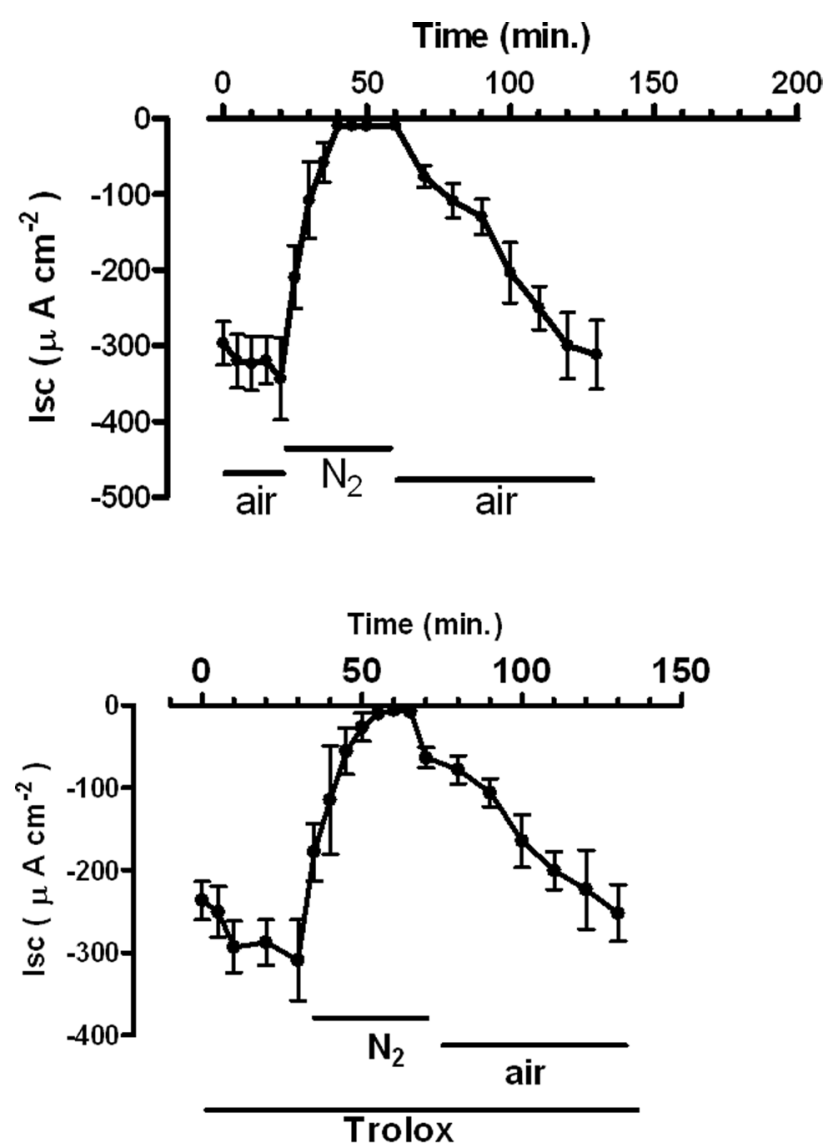

Fig.8 Time-course of the short-circuit current (Isc) in the hemilamella of the posterior gill of shore crab Carcinus maenas in the control group compared with this treated by Trolox C. Both sides of the epithelia were perfused initially and during the phase of reoxygenation with aerated saline. Upon hypoxia of the both sides of epithelia Isc was reduced $97 \%$ during $20 \mathrm{~min}$. In the next $40 \mathrm{~min}$ reoxigenation Isc value was almost fully recovered. Values are means \pm S.E.M. for four individual samples (upper figure). Both sides of hemilamella were incubated with $200 \mu \mathrm{M}$ Trolox. After reached steady-state, upon hypoxia Isc was reduced for $98 \%$ in $20 \mathrm{~min}$. In the next $40 \mathrm{~min}$. Isc was recovered. Mean values for three individual samples \pm S.E.M. per time point are given

incubation of both sides of the hemilamella with Trolox C Isc decreased from $-275.12 \pm 33.2 \mathrm{~A} \mathrm{~cm}^{-2}$ (normoxia) to $-7.9 \pm 3.5 \mathrm{~A} \mathrm{~cm}^{-2}$ (hypoxia), $97 \%$ inhibition in $20 \mathrm{~min}$, consistent with the results of the control group. At $40 \mathrm{~min}$. reoxygenation the Isc was recovered in both groups (Fig. 8, upper and lower figure).

\section{Discussion}

We examined the energetic consequences of hypoxia in the posterior gill epithelium of the hyperosmoregulating crab on the active ionic transport rate measured by Isc, specifically, the $\mathrm{Na}^{+}, \mathrm{K}^{+}$-ATPase activity and $\mathrm{K}^{+}$and $\mathrm{Cl}^{-}$channels.
Based on present data Isc could be inhibited by deoxygenation of the basolateral side but not the apical side. During reoxygenation phase, Isc was fully recovered. The chitinous cuticle barrier present at the apical side hinders $\mathrm{O}_{2}$ diffusion (Taylor and Butler 1978). Higher basolateral than apical oxygen consumption is present because densely-packed mitochondria are particularly there expressed in DSW-acclimated crabs (Compere et al. 1989; Lucu and Ziegler 2017). The mitochondrial respiratory chain uses oxygen to generate ATP which is consumed mainly by $\mathrm{Na}^{+}, \mathrm{K}^{+}$-ATPase for the functioning of primary and secondary active ionic transport processes (Henry et al. 2012).

Reversible inhibition of Isc in Carcinus hemilamella that is, a decline in active ion transport energy supply, downregulates metabolic processes to save energy during oxygen deprivation. Inhibition of Isc in Carcinus hemilamella was caused preferentially by inhibition of basolaterally located ouabain-sensitive $\mathrm{Na}^{+}, \mathrm{K}^{+}$-ATPase (Lucu and Ziegler 2017). In the mucosa-submucosa preparations from human colon, the Isc and transepithelial resistance under hypoxia were transiently decreased (Carra et al. 2011, 2013). If hypoxia in rat colonic epithelium is shifted enough to prevent damage to the epithelium or pump, Isc is fully recovered after reoxygenation (Saravi et al. 2017).

In the present study was found a significant decrease in the $\mathrm{Na}^{+}, \mathrm{K}^{+}$-ATPase specific activity in the posterior gills of DSW- acclimated crabs Carcinus exposed to severe hypoxia. When Carcinus was acclimated in dilute seawater, $\mathrm{Na}^{+}, \mathrm{K}^{+}$-ATPase specific activity had increased in the posterior gills, and in line with these results, Western blotting showed an increased amount of the $\mathrm{Na}^{+}, \mathrm{K}^{+}$-ATPase protein (Lucu and Flik 1999). The data presented here revealed that the intensity of the Western blotting band representing the catalytic subunit of $\mathrm{Na}^{+}, \mathrm{K}^{+}$-ATPase remained high and was not changed in oxygenated, hypoxic and reoxygenated posterior gills. Highly expressed alpha catalytic subunits during short-term hypoxia could be beneficial for reversible enzyme recovery during reoxygenation. Similarly, in the gills and kidney of the Amazonian cichlid fish Astronotus ocellatus exposed to hypoxia, a downregulation of $\mathrm{Na}^{+}, \mathrm{K}^{+}$-ATPase was found, and the catalytic alpha subunit protein abundance was not changed suggesting that the rapid modulation of the enzyme responding to hypoxia is due to post-translational modification (Richards et al. 2007). Suppression of $\mathrm{Na}^{+}, \mathrm{K}^{+}$-ATPase during aestivation of the land snail Otala lactea was linked to posttranslational modification of the enzyme (Ramnanan and Storey 2006). The activity of $\mathrm{Na}^{+}, \mathrm{K}^{+}$-ATPase in trout hepatocytes was decreased by hypoxia. Authors speculated that decrease in $\mathrm{Na}^{+}, \mathrm{K}^{+}$-ATPase activity in response to hypoxia may be accomplished by changes in ROS levels, but no precise mechanism was given (Bogdanova et al. 2005). The present study demonstrates that fasted crabs recovered the 
$\mathrm{Na}^{+}, \mathrm{K}^{+}$-ATPase activity by using internal metabolic sources following 3 days reoxygenation. Hypoxia tolerant brackish water Crustacea are faced with changing of multiple environmental factors - they have the ability of conservation of glycogen as a raw material for ATP production. Stores of glycogen in the hepatopancreas, muscle, and other tissues allow crabs to survive hypoxia (Storey and Storey 2004; Marqueze et al. 2011). Carcinus maenas tolerate up to $10 \mathrm{ppt}$ salinity and oxygen content of ambient water of $1.4 \mathrm{mg} \mathrm{L}^{-1}$ for $24 \mathrm{~h}$, without switching to anaerobic metabolism (Legeay and Massabuau 2000).

Inhibition of the gill $\mathrm{Na}^{+}, \mathrm{K}^{+}$-ATPase specific activity under hypoxia and recovery of the enzyme activity after reoxygenation corroborate by studies on the electrophysiology of isolated gill hemilamella. Isc ion transport activity i.e. electrogenic ion transport fueled predominantly by the Na,K-ATPase activity (Onken and Siebers 1992; Riestenpatt et al. 1996; Lucu and Flik 1999). Our results show inhibition of $\mathrm{Na}^{+}, \mathrm{K}^{+}$-ATPase generated transport at the basolateral side by hypoxia and recovery after reoxygenation. When exposed to hypoxia cells develop adaptive strategies to maintain appropriate level of ATP. These strategies include decreasing energy-consuming processes such as $\mathrm{Na}^{+}, \mathrm{K}^{+}$-ATPase activity. The ability to suppress cellular ATP demand to match the limited capacity for $\mathrm{O}_{2}$-independent ATP production has emerged as the unifying adaptive strategy ensuring hypoxia survival (Hochachka et al. 1996). In the lung alveolar cells $\mathrm{Na}^{+}$pump activity is regulated through the endocytosis / exocytosis of the enzyme molecules between the plasma membrane and intracellular compartments (Bertorello et al. 1999; Dada et al. 2003).

To study whether hypoxia affects the $\mathrm{K}^{+}$and $\mathrm{Cl}^{-}$channels in the Carcinus gill preparation, we used in the present study CsCl (Gögelein 1990) and NPPB non-specific blockers of $\mathrm{K}^{+}$and $\mathrm{Cl}^{-}$channels, respectively, in hyperosmoregulating crabs (Onken et al. 1992, 2003; Riestenpatt et al. 1996; Lucu and Towle 2010). Blocking of the $\mathrm{K}^{+}$channels by $\mathrm{Cs}^{+}$ tended not to change Isc at the onset of hypoxia. Hypoxia has the same degree of effect on Is as that caused by $\mathrm{CsCl}$. Whether these $\mathrm{K}^{+}$channels are affected directly by the reduced $\mathrm{O}_{2}$ level or by the another factor that is generated as a result of hypoxia remains to be determined. The effect of inhibition of the basolateral $\mathrm{K}^{+}$channels abolishes $\mathrm{K}^{+}$ recycling to the lumen which is essential for salt absorption (Riestenpatt et al. 1996; Onken et al. 2003; Lucu and Towle 2010). $\mathrm{Cs}^{+}$-sensitive $\mathrm{K}^{+}$channels located in the basolateral membrane translocate $\mathrm{K}^{+}$and $\mathrm{NH}_{4}$ ions from the hemolymph of Carcinus into the basolateral cytoplasm of the gill epithelium (Weihrauch et al. 2004). One of the primary functions of the basolateral $\mathrm{K}^{+}$channels is to recycle $\mathrm{K}^{+}$ across the basolateral membrane for the proper functioning of the $\mathrm{Na}^{+}, \mathrm{K}^{+}$-ATPase (Hamilton and Devor 2012). In the crab gills, the basolaterally located potassium channel is a major determinant of the negative cell membrane potential. In the hyperosmoregulating crab gills apical $\mathrm{K}^{+}$channels have a role to enable $\mathrm{K}^{+}$for $\mathrm{Na}^{+} / \mathrm{K}^{+} / 2 \mathrm{Cl}^{-}$cotransporter function. The cotransporter loads $\mathrm{Cl}^{-}$into the cell and leaving the cell across basolateral $\mathrm{Cl}^{-}$channel (Riestenpatt et al. 1996). In transcriptome studies hyperpolarization-activated cyclic nucleotide-gated potassium channel of the posterior gill epithelium of Carcinus is down-regulated by short-term hypercapnia (Fehsenfeld et al. 2011). The activity of this $\mathrm{K}^{+}$ channel is significantly decreased in response to respiratorymetabolic acidosis during high environmental $\mathrm{P}_{\mathrm{CO} 2}$ (Fehsenfeld and Weihrauch 2016). In the isolated rat distal colon, the pivotal role of $\mathrm{K}^{+}$channels was underlined by the action of $\mathrm{Ba}^{2+}$ which suppressed the peak in the Isc during hypoxia (Schindele et al. 2016).

The present study examined the effect of hypoxia on Isc in combination with $\mathrm{Cl}^{-}$channel blocker NPPB. Combined effects inhibits more than $90 \%$ of Isc. Only hypoxia inducible portion of Isc was recovered during reoxygenation. The $\mathrm{Cl}^{-}$channels are involved in numerous functions in transepithelial transport, cell volume regulation, stabilizing membrane potential, synaptic inhibition and extracellular acidification (Jentsch et al. 2005). In the rat's distal colon, NPPB suppressed the Isc induced by hypoxia and reduced the secondary rise of the Isc during reoxygenation (Schindele et al. 2016). Based on the transcriptome analyses that showed changes in the gill epithelium cells of $C$. maenas after one week exposure to $400 \mathrm{~Pa}_{\mathrm{pCO}}$, significant changes in a $\mathrm{Ca}^{2+}$-activated $\mathrm{Cl}^{-}$channel, a hyperpolarization-activated nucleotide-gated $\mathrm{K}^{+}$channels and a $\mathrm{Cl}^{-} / \mathrm{HCO}_{3}{ }^{-}$exchanger were suggested (Fehsenfeld et al. 2011).

We found that the elevated level of catalase in the gills of crabs acclimated to DSW remain up-regulated during hypoxia and reoxygenation. A significant increase in catalase and superoxide dismutase under hyposmotic stress condition was observed in posterior gills of Carcinus aestuarii (Rivera-Ingraham et al. 2016). Moreover, assuming an antioxidant role of metallothyonein (MT) associated with intracellular partitioning, the observed MT induction in posterior gills of Carcinus aestuarii may be considered as an adaptive response to hyposmotic stress (Lucu et al. 2008). Posterior gills showed a higher antioxidant enzyme activity than the anterior gills (de Oliveira et al. 2005).No increase in the activities of the antioxidant enzyme in the posterior gills of Callinectes danae and $C$. ornatus was noticed upon hypo- salinity stress (Freire et al. 2011). No change in expression of catalase during exposure to hypoxia was found in muscle of the pelagic crab Pleuroncodes planipes (Seibel et al. 2018). In the posterior gills of the crab Chasmagnathus granulata (Neohelice granulata), the activity of catalase and glutathione S-transferase were increased mostly when the crab was exposed to anoxia (de Oliveira et al. 2005). During exposure of the crab Neohelice granulata 
to hypoxia, the locomotor muscle reactive oxygen species (ROS) and lipid peroxidase activity were briefly increased during reoxygenation and quickly recovered (Geihs et al. 2013). Over-expression of the antioxidant enzyme catalase acts against free radicals, preventing the hypoxia-mediated $\mathrm{Na}^{+}, \mathrm{K}^{+}$-ATPase degradation in air-breathing fish and trout hepatocytes (Huang et al. 2015).

In the presence of $\mathrm{N}_{2}$, exposure of $\mathrm{H}_{2} \mathrm{O}_{2}$ produced an initial slight decrease of Isc with subsequent increase. It seems that $\mathrm{H}_{2} \mathrm{O}_{2}$. does not participate in ROS signaling, it is more likely blocking detection of hypoxia, by supplying $\mathrm{O}_{2}$ through its decomposition by catalase and/or peroxidases. The initial decrease in the Isc was probably affected by hypoxia and/or the relatively high initial $\mathrm{H}_{2} \mathrm{O}_{2}$ concentration penetrating the epithelium during the first few minutes and partially blocking the Isc. After $\mathrm{H}_{2} \mathrm{O}_{2}$ partial decomposition to $\mathrm{O}_{2}$ and $2 \mathrm{H}_{2} \mathrm{O}$ by catalase and peroxidase activities in the epithelium (Lyons et al. 2014), the liberated oxygen in the saline may affect the rise of the Isc. During reoxygenation, the Isc continued to increase to baseline level. The result exhibit high tolerance of Carcinus to cope with highly toxic hydrogen peroxide which does not participate at concentration $2 \mathrm{mM}$ in ROS signaling. Exogenous exposure of one of the most toxic oxygen species, hydrogen peroxide, depresses the $\mathrm{Na}^{+}, \mathrm{K}^{+}$-ATPase activity in vertrebrates (Clerici et al. 1992; Wong et al. 2014). Brain $\mathrm{Na}^{+}, \mathrm{K}^{+}$-ATPase has been found to be more sensitive than kidney enzyme to inhibition by $\mathrm{H}_{2} \mathrm{O}_{2}$ in mammals (Kurella et al. 1999). It has been suggested that $\mathrm{H}_{2} \mathrm{O}_{2}$ is a signaling messenger that causes the -catalytic subunits of $\mathrm{Na}^{+}, \mathrm{K}^{+}$-ATPase to become sensitive to modification by hypoxia by targeting thiol oxygen groups of these subunits (Bogdanova et al. 2016). It is hypothesised that $\mathrm{H}_{2} \mathrm{O}_{2}$ action affects ATP, subsequently inhibiting apical membrane $\mathrm{Cl}^{-}$conductance or altering action of transporters directly (Du Vall et al. 1998).

To study whether radicals, which are known to act as intracellular signaling molecules (Dröge 2003), play a role in the current induced by hypoxia/reoxygenation, hemilamella was treated with a ROS scavenger, the antioxidant Trolox C a water soluble analogue of vitamin $\mathrm{E}$. Trolox $\mathrm{C}$ was previously used to reduce oxidative stress damage in vertebrate epithelia (Vergauwen et al. 2015; Schindele et al. 2016). No difference in the level and time-dependent Isc inhibition by hypoxia and reoxygenation of the gill hemilamella between the group treated with Trolox $\mathrm{C}$ and the control group was found. This lack of change in the Isc after incubation of gill hemilamella with Trolox $\mathrm{C}$ during hypoxia and reoxygenation phases suggests the relatively high capacity of the epithelium to deal with free radical production or that the hypoxia signal is not transduced by ROS signaling during hypoxia and reoxygenation. In the hypoxic rat colonic epithelium, the secondary decrease in the Isc was significantly reduced by Trolox (Schindele et al. 2016).
In summary, our study revealed that in the posterior gill epithelium layer mounted in a Ussing-type chamber, hypoxia induced basolateral inhibition of the Isc. In crabs exposed to acute severe hypoxia, the posterior gills showed decreased $\mathrm{Na}^{+}, \mathrm{K}^{+}$-ATPase specific activity without changes in the $\mathrm{Na}^{+}, \mathrm{K}^{+}$-ATPase alpha subunit protein abundance. Fasted crabs recovered $\mathrm{Na}^{+}, \mathrm{K}^{+}$-ATPase activity by using internal metabolic sources following 3 days reoxygenation. To keep ATP homeostasis, cells can decrease ATP demands via inhibition of ATP-consuming enzymes i.e. by reducing specific activity of $\mathrm{Na}^{+}, \mathrm{K}^{+}$-ATPase. In the gill epithelium layer of hyperosmoregulating $C$. maenas, a non-specific inhibitor of $\mathrm{K}^{+}$channels $\mathrm{Cs}^{+}$, applied basolaterally, inhibited the Isc within the same order of magnitude as hypoxia. Combined effects of hypoxia and NPPB blocks more than $90 \%$ of Isc. Upon subsequent reoxygenation, NPPB induced inhibition of Isc was not recovered. During hypoxia and reoxygenation, the antioxidant enzyme catalase sustained the same high level as that observed in the control DSW acclimated crabs. An initial slight decrease in Isc impaired by $2 \mathrm{mM} \mathrm{H}_{2} \mathrm{O}_{2}$ was followed by a rise and full recovery of Isc after reoxygenation. Results showed that Trolox $\mathrm{C}$ was unable to change hypoxia-induced Isc transport generated by $\mathrm{Na}^{+}, \mathrm{K}^{+}$-ATPase. The lack of Trolox $\mathrm{C}$ effect suggest that the ROS signaling does not mediate changes in hypoxia inhibition and reoxygenation of the isolated gill epithelium.

Acknowledgements This work and visit of Č.L. to AWI was supported by Alexander von Humboldt Foundation, Bonn, Germany. Thanks to Dr Kerstin Moelter, and Dr Lisa Shama from Alfred Wegener Institute for Polar Research and Marine Studies from List/Sylt and Sonja Hauke from Humboldt foundation for kind support. Preliminary studies with Dr. Mathias Wegner on the the effects of hypoxia on crab hemocytes were fully appreciated. Thank's to Birgit Hussel and Petra Kadel for kind technical help. This work was funded by Alexander von Humboldt-Stiftung with Grant number HRV 1016916HFST.

\section{References}

Barra JA, Pequeux A, Humnbert W (1983) A morphological studies on gills of a crab acclimated to freshwater. Tissue Cell 15:583-596

Berenbrink M, Koldkjaer P, Kepp O, Cossins AR (2005) Evolution of oxygen secretion in fishes and emergence of a complex physiological system. Science 307:1752-1757

Bertorello AM, Ridge KM, Chibalin AV, Katz AI, Sznajder JI (1999) Isoproterenol increases $\mathrm{Na}^{+}, \mathrm{K}^{+}$-ATPase activity by membrane insertion of $\alpha$-subunits in lung alveolar cells. Am J Physiol 276:L20-L27

Bogdanova AI, Nikinmaa M (2001) Reactive oxygen species regulate oxygen sensitive potassium flux in rainbow trout erythrocytes. $\mathbf{J}$ Gen Physiol 117:1172-1181

Bogdanova AI, Grenacher B, Nikinmaa M, Gassmann M (2005) Hypoxic responses of $\mathrm{Na}^{+} / \mathrm{K}^{+}$-ATPase in trout hepatocytes. J Exp Biol 208:1793-1801

Bogdanova A, Petrushanko IY, Hemansanz-Augustin P, Martinez-Ruiz A (2016) "Oxygen sensing" by Na,K-ATPase: these miraculous thiols. Front Physiol 7:314 
Boutilier RG, St Pierre J (2000) Surviving hypoxia without really dying. Comp Biochem Physiol 126A:481-490

Burnett LE, Stickle WB (2001) Physiological responses to hypoxia. In: Rabalais NN, Taylor RE (eds) Coastal hypoxia. American Geophysical Union, Washington, pp 104-114

Carra GE, Ibáñez JE, Saraví FD (2011) Electrogenic transport, oxygen consumption, and sensitivity to acute hypoxia of human colonic epithelium. Int J Colorectal Dis 26:1205-1210

Carra GE, Ibanez JE, Saravi FD (2013) The effect of acute hypoxia on short-circuit current and epithelial resistivity in biopsies from human colon. Dig Dis Sci 9:2499-2506

Chantel M, Claude S (2005) Response of the blue shrimp Litopenaeus stylirostris to temperature decrease and hypoxia in relation to molt stage. Aquacult 244:315-322

Charmantier G, Soyez C, Aquacop C (1994) Effects of molt stage and hypoxia on osmoregulatory capacity in the peneid shrimp Penaeus vannamei. J Exp Mar Biol Ecol 178:233-246

Cheng WT, Liu CH, Kuo CM (2003) Effects of dissolved oxygen in hemolymph parameters of freshwater giant prawn Macrobrachium rosenbergii. Aquaculture 220:843-856

Claiborne A (1985) Catalase activity. In: Greenwald RA (ed) CRC Handbook of methods for oxygen radical research. CAC, Boca Raton, pp 283-284

Claiborne JB, Edwards SL, Morrison-Shetlar AI (2002) Acid-base regulation in fishes: cellular and molecular mechanisms. J Exp Zool 293:302-319

Clerici C, Friedlander G, Amiel C (1992) Impairment of sodium-coupled uptake by hydrogen peroxide in alveolar type cells: protective effect of $\alpha$-tocopherol. Am J Physiol 262:L542-L548

Compere PH, Wanson S, Pequeux A, Gilles R, Goffinet G (1989) Ultrastructural changes in the gill epithelium of the green crab Carcinus maenas in relation to the external salinity. Tissue Cell 21:299-318

Dada LA, Chandel NS, Ridge KM, Pedemonte C, Bertorello AM, Sznajder JI (2003) Hypoxia-induced endocytosis of Na,K-ATPase in alveolar epithelial cells is mediated by mitochondrial reactive oxygen species and PKC-zeta. J Clin Invest 111:1057-1064

Dawson DC, Richards NW (1980) Alabaster K conductance: role in regulation of $\mathrm{NaCl}$ reabsorption and secretion. Am J Physiol 259:C181-C195

de Oliveira UO, da Rosa Aranjo, Bello Klein A, da Silva RS, Kucharski LC (2005) Effects of environmental anoxia and different periods of reoxygenation on oxidative balance in gills of the estuarine crab Chasmagnathus granulata. Comp Biochem Physiol 14(1):51-57

Diaz RJ, Rosenberg R (2008) Spreading dead zones and consequences for marine ecosystems. Science 321:926-928

Durand F, Regnauld M (1998) Nitrogen metabolism of two portunid crabs, Carcinus maenas and Necora puber during prolonged air exposure and subsequent recovery: a comparative study. J Exp Biol 201:2515-2528

Du Vall MD, Guo YI, Mataloni S (1998) Hydrogen peroxide inhibits cAMP-induced $\mathrm{Cl}$ secretion across colonic epithelial cells. Am J Physiol 275:C1313-C1322

Falconer TRL, Marsden ID, Hill V, Glover CN (2019) Does physiological tolerance to acute hypoxia and salinity change explain ecological nishe in two intertidal crab species. Conserv Physiol 7:13

Fehsenfeld S, Weihrauch D (2016) The role of an ancestral hyperpolarization-activated cyclic nucleotide-gated $\mathrm{K}^{+}$channel in branchial acid-base regulation in the green crab, Carcinus maenas. J Exp Biol 219:887-896

Fehsenfeld S, Kiko R, Appellhans YD, Towle DW, Zimmes M, Melzner $\mathrm{F}$ (2011) Effects of elevated seawater $\mathrm{pCO}_{2}$ on gene expression patterns in the gills of the green crab Carcinus maenas. BMC Genom 12(488):2-17

Freire CA, Togni VG, Hermes-Lima M (2011) Responses of free radical metabolism to air exposure or salinity stress in crabs
(Callinectes danae and C. ornatus) with different estuarine distributions. Comp Biochem Physiol 160:291-300

Geihs MA, Maciel FE, Vargas MA, Cruz BP, Nery LEM (2013) Effect of hypoxia and reoxygenation on the energetic metabolism of the crab Neohelice granulata (Decapoda, Varunidae). J Exp Mar Biol Ecol 445:69-78

Gögelein H (1990) Ion channels in mammalian proximal tubules. Renal Physiol Biochem 13:8-25

Gorr TA, Gassmann M, Wappner P (2006) Sensing and responding to hypoxia via HIF in model invertebrates. J Insect Physiol $52: 349-364$

Guppy M, Fuery CJ, Flanigan JE (1994) Biochemical principles of metabolic depression. Comp Biochem Physiol 109B:175-189

Hagerman L, Uglow RF (1981) Ventilatory behaviour and chloride regulation in relation to oxygen tension in the shrimp Palaemon adspersus Rathke maintained in hypotonic medium. Ophelia 20:193-200

Hamilton KL, Devor DC (2012) Basolateral membrane $\mathrm{K}^{+}$-channels in renal epithelial cells. Am J Physiol 302:F1069-F1081

Henry RP, Lucu Č, Onken H, Weihrauch D (2012) Multiple functions of the crustacean gill:osmotic/ionic regulation, acid-base balance, ammonia excretion, and bioaccumulation of toxic metals. Front Physiol 3:431

Hill AD, Taylor AC, Strang RHC (1991) Physiological and metabolic responses of shore crab Carcinus maenas (L.) during environmental anoxia and subsequent recovery. J Exp Mar Biol Ecol 150:31-50

Hochachka PW, Somero GN (2002) Biochemical adaptation: mechanism and process in physiological evolution. Oxford University Press, New York, p 466

Hochachka PW, Buck LT, Doll CJ, Land SC (1996) Unifying theory of hypoxia tolerance molecular/metabolic defense and rescue mechanisms for surviving. Proc Nat Acad Sci USA 93:9493-9498

Huang CY, Lin HC, Liu CH (2015) Effects of hypoxia on ionic regulation, glycogen utilization and antioxidative ability in the gills and liver of aquatic air breathing fish Trichogaster microlepis. Comp Biochem Physiol 179A:25-34

Jentsch TJ, Stein V, Weinreich G, Zdebik AA (2005) Molecular structure and physiological function of chloride channels. Physiol Rev 82:503-568

Johnson I (1988) The effects of combination of heavy metals, hypoxia and salinity on ion regulation in Crangon crangon (L.) and Carcinus maenas (L.). Comp Biochem Physiol 9:459-463

Johnson I, Uglow RF (1987) The effects of hypoxia on ion regulation and acid-base balance in Carcinus maenas (L.). Comp Biochem Physiol 86A:261-267

Jonz MG, Fearon IM, Nurse CA (2004) Neuroepithelial oxygen chemoreceptors of the zebrafish gill. J Physiol 560:737-752

Kurella EG, Tyulina OV, Boldyrev AA (1999) Oxidative resistance of Na,K-ATPase. Cell Mol Neurobiol 19:133-140

Larade K, Storey KB (2002) Reversible suppression of protein synthesis in concert with polysome disaggregation during anoxia exposure in Littorina littorea. Mol Cell Biochem 232:121-127

Le Z, Langhans SA (2015) Transcriptional regulators of Na,K-ATPase subunits. Front Cell Develop Biol 3:66

Legeay A, Massabuau JC (2000) Effect of salinity on hypoxia tolerance of resting green crab Carcinus maenas, after feeding. Mar Biol 136:387-396

Leignel VSJH, Baringou S, Thabet L, Metais I (2014) Overview of the European green crab Carcinus sp. (Portunidae, Decapoda), one of the most famous marine invaders and ecotoxicological models. Environ Sci Poll Res 21:9129-9144

Liu HP, Chen FY, Gopalakrishnan S, Qiao K, Bo Y, Wang KJ (2010) Antioxidant enzymes from the crab Scylla paramanosian :gene cloniong and gene/protein expression onb profil against LPS challenge. Fish Shellfish Immunol 28:862-871 
Lopez-Barneo J, Ortega-Saens P, Molina A, Franco-Obregon AUK, Castellano A (1997) Oxygen sensing by ion channels. Kidney Int 51:454-461

Lucu Č, Flik G (1999) $\mathrm{Na}^{+}, \mathrm{K}^{+}$-ATPase and $\mathrm{Na}^{+} / \mathrm{Ca}^{2+}$ exchange activities in gills of hyperregulating Carcinus maenas. Am J Physiol 276:R490-R499

Lucu Č, Towle DW (2010) Characterization of ion transport in the isolated epipodite of the lobster Homarus americanus. J Exp Biol 213:418-452

Lucu Č, Ziegler A (2017) The effects of hypoxia on active ionic transport processes in the gill epithelium of hyperregulating crab Carcinus maenas. Comp Biochem Physiol 211A:61-68

Lucu Č, Pavičić J, Ivanković D, Pavičić-Hamer D, Najdek M (2008) Changes in Na,K-ATPase activity, unsaturated fatty acids and metallothioneins in gills of the shore crab Carcinus aestuarii after dilute seawater acclimation. Comp Biochem Physiol 149A:362-372

Lundgreen SK, Kiilerich P, Tipsmark CT, Madsen SS, Jensen FB (2008) Physiological response in the European Xounder (Platichthys flesus) to variable salinity and oxygen conditions. J Comp Physiol 178B:909-915

Lyons MC, Wong DKH, Paye EH (2014) Degradation of hydrogen peroxide in seawater using the anti-sealous formulation. Interox Paramon 50. Canad Tech Rep Fish Aquat Sci 3080:1-26

Maciel FE, da Rosa CE, Santos EA, Monserrat JM, Nery LEM (2004) Daily variations in oxygen consumption antioxidant defenses and lipid peroxidation in the gills and hepatopancreas of an estuarine crab. Can J Zool 82:1871-1877

Mairbaurl H, Mayer K, Kim J, Borok Z, Bartch P, Crandall ED (2002) Hypoxia decreases active Na transport across primary rat alveolar epithelial cell monolayer. Am J Physiol 282:L659-L665

Marqueze A, Ribarcki F, Kirst I, Kucharski LC, Silva RSM (2011) Glucose metabolism. The hepatopancreas of the crab Neohelice granulata maintained on carbohydrate-rich or high protein diets: anoxia and recovery. J Exp Mar Biol Ecol 404:40-46

Neufeld GJ, Holliday SW, Prichard JB (1980) Salinity adaptation of gill Na,K-ATPase in the blue crab Callinectes sapidus. J Exp Zool 211:215-224

Onken H, Siebers D (1992) Voltage-clamp measurements on single split lamella of posterior gills of the shore crab Carcinus maenas. Mar Biol 114:385-390

Onken H, Tresguerres M, Luquet CM (2003) Active NaCl absorption across posterior gills of hyperosmoregulating Chasmagnatus granulatus. J Exp Biol 206:1017-1023

Planes C, Friedlander G, Loiseau AS, Amiel C, Clerici C (1996) Inhibition of Na,K-ATPase activity after prolonged hypoxia in an alveolar epithelial cell line. Am J Physiol 271:L70-L78

Ramnanan CJ, Storey RB (2006) Supression of $\mathrm{Na}^{+}, \mathrm{K}^{+}$-ATPase activity during estivation in the land snail Otala lactea. J Exp Biol 209:677-688

Richards JG, Wang YS, Brauner CJ, Gonzalez RJ, Patrick ML, Schulte PM, Choppari-Gomes AR, Almeida-Val VM, Val AL (2007) Metabolic and ionoregulatory responses of the Amazonian cichlid, Astronotus ocellatus, to severe hypoxia. J Comp Physiol 177:361-374

Riedel B, Zuschin M, Stachowitsch M (2012) Tolerance of benthic macrofauna to hypoxia and anoxia in shallow coastal seas: a realistic scenario. Mar Ecol Prog Ser 458:39-52

Riestenpatt S, Onken H, Siebers D (1996) Active absorption of $\mathrm{Na}^{+}$and $\mathrm{Cl}^{-}$across the gill epithelium of the shore crab Carcinus maenas: voltage-clamp and ion-flux studies. J Exp Biol 199:1545-1554

Rivera-Ingraham GA, Barri K, Boel M, Farey E, Charles AL, Geny B, Lignot JH (2016) Osmoregulation and salinity induce oxidative stress: is oxidative adaptation determined by gill function? J Exp Biol 219:80-89
Saravi FD, Carra GE, Matus A, Ibanez JE (2017) Rectification of oxygen transfer through the rat colonic epithelium. World J Gastrointest Pathophysiol 8:59-66

Schindele S, Pouokamen E, Diener M (2016) Hypoxia/reoxygenation effects on ion transport across rat colonic epithelium. Front Physiol 7:247

Schvezov N, Lovrich GA, Romero MC (2017) Oxidatide stress during re-immersion of the king crab Lithodes santolla (Molina, 1782) (Decapoda: Anomura: Lithodidae) after air exposure. J Crustac Biol 37:195-203

Seibel B, Luu BE, Tessier SN, Towanda T, Storey KB (2018) Metabolic supression in the pelagic crab Pleuroncodes planipes in oxygen minimum zone. Comp Biochem Physiol 224B:88-97

Shimoda LA, Polak J (2011) Hypoxia. 4. Hypoxia and ion channel function. Am J Physiol 300:C951-C967

Siebers D, Winkler A, Lucu Č, Thedens G, Weichart D (1985) Na,KATPase generates an active transport potential in the gills of hyperosmoregulating shore crab Carcinus maenas. Mar Biol $87: 185-192$

Dröge W (2003) Oxidative stress and aging. In: Roach RC, Wagner PD, Hackett PH (Eds) Hypoxia. Adv Exp Medicine 543: 191-200, Springer, Boston.

Storey KB, Storey JM (1990) Facultative metabolic rate depression: molecular regulation and biochemical adaptation in anaerobiosis, hibernation, and estivation. Q Rev Biol 65:145-174

Storey KB, Storey JM (2004) Tribute to P. L. Lutz: putting life on 'pause'-molecular regulation of hypometabolism. J Exp Biol 210:1700-1714

Taylor EW, Butler PJ (1978) Aquatic and aerial respiration in the shore crab Carcinus maenas (L.) acclimated to $15^{\circ} \mathrm{C}$. J Comp Physiol 127:315-323

Van Driessche W, Zeiske W (1985) Ionic channels in epithelial cell membranes. Physiol Rev 65:833-903

Vergauwen H, Tambuyzer B, Jennes K, Degroote J, Wang WS, De Smet $S$ (2015) Trolox and ascorbic acid reduce direct and indirect oxidative stress in the IPEC-J2 cells, an in vitro model for the porcine gastrointestinal tract. PLoS One 10

Weihrauch D, Morris S, Towle DW (2004) Ammonia excretion in aquatic and terrestrial crabs. J Exp Biol 207:4491-4504

Wodopia RK, Billian J, Wiesner R, Bartsch P, Mairbaurl H (2000) Hypoxia decreases proteins involved in epithelial electrolyte transport in A549 cells and rat lung. Am J Physiol 279:L1110-L1119

Wong PS, Garle MJ, Alexander SPH, Randall MD, Roberts RE (2014) A role for the sodium pump in $\mathrm{H}_{2} \mathrm{O}_{2}$-induced vasorelaxation in porcine isolated coronary arteries. Pharmacol Res 90:25-35

Wood CM, Grossel M (2015) Electrical aspects of the osmoregulatory compromise: TEP responses to hypoxia in the euryhaline killifish (Fundulus heteroclitus) in freshwater and seawater. J Exp Biol 218:2152-2155

Wood CM, Kajimuran M, Sloman KA, Scott GR, Walsh PJ, AlmeidaVal VM, Val AL (2007) Rapid regulation of Na fluxes and ammonia excretion in response to acute environmental hypoxia in the Amazonian oscar, Astronotus ocellatus. Am J Physiol 292:R2048-R2205

Zacher PC, Pan W, Jons MG (2017) Characterization of ion channels and $\mathrm{O}_{2}$ sensitivity in gill neuroepithelial cells of the anoxia tolerant goldfish (Carassius auratus). J Neurophysiol 118:3014-3023

Publisher's Note Springer Nature remains neutral with regard to jurisdictional claims in published maps and institutional affiliations. 